\title{
Development of an extruded food product similar to fried potatoes, based on by-products of potatoes and rice. physicochemical and microbiological evaluation
}

\author{
Laura ALMENDARES CALDERÓN ${ }^{1 *}$ (i), Verónica Alejandra GARCÍA MENA ${ }^{1}$ José Manuel ROMÁN MIRANDA
}

\begin{abstract}
The FAO and the OMS have warned on the high risk to health from the consumption of fried food due to their high energy density (fats) which leads to obesity, heart problems and the development of toxic compounds, like acrylamide, produced in frying oils. Chile has high obesity indices in adults, who affect $25.1 \%$ of the population. A fundamental cause is the increasing consumption of trashed food, like fried potatoes as an inevitable component. This is due mainly to the fact that fats and carbohydrates activate areas of the brain related to pleasure, leading to addiction. In this paper deals with an extruded food product similar to fried potatoes in configuration and organoleptic characteristics; made with raw materials of low commercial value. This product is aimed at producing a food similar to fried potatoes, but with low oil absorption capacity during frying, allowing to offer a healthier alternative to the population. The oil absorption for the samples submitted in both extrusions, were lower than in the commercial product. This fact presents the challenge of obtaining a prototype that generates a lower absorption of oil, realizing the changes that are already glimpsed with the preliminary tests carried out.
\end{abstract}

Keywords: extrusion; potato; rice; obesity.

Practical Application: The application of this work was to obtain a wealthy alternative to the fried potatoes with lower oil absorption.

\section{Introduction}

The Food and Agriculture Organization of the United Nations (1997a, b) indicate that the high consumption of fried food is a risk factor for health, mainly because of its high energy density, which appears at the expense of fat and for the formation of toxic compounds, mainly acrylamides, which have been related to the development of some kinds of cancer. At present, Chile is found in the sixth place of infantile obesity in the world according to a study made by the Instituto de Nutrición y Tecnología de los Alimentos (Herrera et al., 2017; Vio, 2012). In 2012, 25.1\% of Chile's adult population was obese. According to these obesity levels and increasing trends, the Ministerio de Salud has carried out several programs and has proposed laws meant to decrease the present figures. Furthermore, Chile is a great consumer of trash food at the Latin American level, with 41\% of the population consuming this kind of food. Recently, poor feeding has generated a number of health problems in people all over the world, causing the appearance of a set of chronic intransmissible diseases that are started mainly through foods like sugary drinks, alcohol, fried food, fast food, and sandwiches (Durán et al., 2014).

There is no doubt that frying is one of the most widely spread cooking techniques around the world (Veronese et al. 2017), favored in part by the increased consumption of fast food, both at home and outside, with fried potatoes as one of the fried foods preferred by Chileans. As a process, frying is the immersion of a food product in edible oil heated above the boiling point of water (Pedreschi et al., 2005). Frying temperatures are in the range of $120^{\circ} \mathrm{C}$ to $200{ }^{\circ} \mathrm{C}$, but the most common are in the $170{ }^{\circ} \mathrm{C}$ to $190^{\circ} \mathrm{C}$ range (Bouchon, 2002).

In Chile around 50,000 hectares of potatoes are grown annually, making them the fourth largest crop in terms of area and the one that has the largest number of small farmers involved, with 59,606 (INE VII Censo Nacional Agropecuario). The production is meant almost completely for the internal market, and it is an important food in the diet of Chileans. Chile has a variety of native potatoes, making it a genetic heritage for the country (Chile, 2017; Servicio Agrícola y Ganadero, 2012) and a long history in the generation of new varieties (Chile, 2017).

On the other hand, rice (Oryza sativa L.) has a central function in human diet. It is the most important cereal crop in terms of total production in the world and of the number of consumers who depend on it as a basic food. The properties of rice, like its hypoallergenic, mild taste, make it a desirable grain for the development of new foods (Hagenimana et al., 2006).

The chemical composition of the rice grains varies considerably depending on the genetic factor of the variety and the environmental influence, such as the place and the season in which it is grown, the application of fertilizers, the degree of grinding, and the storage conditions. Even then, nowadays with imported and national varieties it can be stated that a sample of polished rice contains, approximately $80 \%$ carbohydrates, $12 \%$ moisture, $6.7 \%$ proteins, $0.5 \%$ ash, $0.4 \%$ lipids, and $0.3 \%$ crude fiber (Hernández \& Sastre, 1999). 
Food extrusion is a very attractive tool used in some industrial processes, mainly for mixing and giving shape to cereals. It is also used to transform a wide variety of raw materials into modified intermediate and/or final products, such as extruded rice, breakfast snacks, etc.

The extrusion process has as a basis the delivery of a given shape to the food, for which end parameters like temperature, moisture, and mixing of the raw materials are controlled, according to formulas created for this purpose (Huang \& Ma, 2015). The number of revolutions of the worm screw, as well as the shearing power, determine the temperature, the degree of gelatinization, and with it the texture and the quality of the product. However, the composition of the starting products also has an influence (Bühler, 2017a, b; Zhang et al., 2015).

Extrusion can modify different food materials to produce a diversity of new products by combining different ingredients and operating conditions that can hardly be generated by other processes. Currently, extrusion technology can allow an infinite amount of new possibilities for processing food matrices (Arias et al., 2007). In this context, our group has developed an extruded food product, similar to fried potatoes in configuration, characteristics and uses, with low oil absorbing capacity during frying, made with Chilean raw materials having low commercial cost.

\section{Materials and methods}

\subsection{Raw materials}

In all the experiment the Desiree variety were used. They were peeled automatically (Hobart peeler) at a speed of $1450 \mathrm{rpm}$. They were then immersed in a $0.6 \% \mathrm{w} / \mathrm{v} \mathrm{Na} \mathrm{N}_{2} \mathrm{O}_{5}$ solution. The potatoes were then chopped up manually with knives and ground in a SKYMSEN, LAR-04MB semi-industrial blender. To get a pressed paste with less than $65 \%$ moisture, its water content was reduced in a handicraft press. The compressed paste was stored in a refrigerator at $5{ }^{\circ} \mathrm{C}$. Knorr ${ }^{\oplus}$ mashed dried potatoes was used as dehydrated potato because it contains fewer additives. Rice flour was obtained from white rice of the diamond variety. The grain was ground in a Brabender mill. For the preliminary tests a mixture of the previously mentioned ingredients was obtained. For samples 1 to 6 the mixtures were made in a semi-industrial mixer (MAIGAS, mod. FAVB20F).

\subsection{Extrusion}

Twin screw extrusion took place at an output temperature range of $50-60^{\circ} \mathrm{C}, 175 \mathrm{rpm}$, and $37.4 \mathrm{psig}$, with a screw length of 1 meter. Processing with single screw extrusion took place in the same temperature range and at the same pressure, but the screw length was $12 \mathrm{~cm}$. For both extrusions, a $7 \mathrm{~mm}$ square-shaped die nozzle was used, and the product was cut manually every $8 \mathrm{~cm}$. The extruded samples were cooled to $4^{\circ} \mathrm{C}$ for 10 days.

\subsection{Frying}

It was done in an electric fryer (SUPER CHACON) with adjustable thermostat. The immersion medium was $100 \%$ sunflower oil (Chef ${ }^{\circledast}$ ). The samples were subjected to pre-frying
( $160 \pm 2{ }^{\circ} \mathrm{C}$ for 30 seconds). The frying conditions were $160 \pm 2{ }^{\circ} \mathrm{C}$ for 90 seconds.

\subsection{Proximate analysis}

Before extruding, the samples were subjected to proximate analysis, considering the moisture content (Nch 841. Of 78), proteins (American Association of Cereal Chemists, 2010), lipids (Association of Official Analytical Chemists, 2012), ash (NCh 842.Of 78), crude fiber (Association of Official Analytical Chemists, 2010), non-nitrogenated extracts (Schmidt-Hebbel, 1981), and energy (Schmidt-Hebbel, 1981).

\subsection{Moisture analysis of the raw materials}

In the case of potatoes and potato paste, the gravimetric determination of mass loss of the dried sample to constant mass in an air oven was performed (Association of Official Analytical Chemists, 1990). For the rice flour and dried potatoes, the method described in NCh 841.Of 78 "Alimentos - Determinación de humedad" (Food - Moisture determination). Finally, in the extruded product the moisture was measured with the $\mathrm{HC} 103$ METTLER TOLEDO $0.01 \%$ equipment, at $105^{\circ} \mathrm{C}$, using $1 \pm 0.02$ grams of sample.

\subsection{Determination of total oil absorption}

The oil absorption determination of the fried samples applied the previously described method using the Soxhlet technique (Bouchon et al., 2003; Association of Official Analytical Chemists, 1984).

\subsection{Microbiological analysis}

Depending on the composition of the product and the later conditions required before consumption, the microbiological analyses required by the Sanitary Food Regulations (Chile, 2013) were performed: Enterobacteriaceae (Association of Official Analytical Chemists, 1997), Staphylococcus aureus (Association of Official Analytical Chemists, 2003) using fast methods on "Petri film" dishes and Salmonella (Association of Official Analytical Chemists, 2000) by the traditional method. Furthermore, counts of mesophilic aerobics (RAM) (Association of Oficial Analytical Chemists, Official method 1990), molds and yeasts (Association of Official Analytical Chemists, 1997), were made by storage period.

\subsection{Statistical analysis}

The data were analyzed using the software GraphPad Prism v.7.0 and the statistical analysis ANOVA two way and the Tukey multiple comparisons test. The significance level used was $\mathrm{P}<0.05$ throughout the study.

\section{Results and discussion}

\subsection{Raw materials analysis}

The determination of the composition of the mixtures was made by the testing - error - correction method, starting from a simple mixture of potato paste - white flour derived from 
rice by-products. Every assay was tested for cohesion, texture, configuration behavior, and frying tests (data not shown). The percentages were reduced to three of potato paste and two of rice flour (Table 1). Additions of dried potato puree and xanthan gum as binder were also made.

The proximate composition of product lots made with each mixture was measured (Table 2). Lower moisture is seen in mixtures 3 and 4 , which contain $10 \%$ of dried potato flour, whose initial moisture was $12 \%$. This factor also causes higher protein content, percentage ash, non-nitrogenated extract, and energy than the rest of the samples (Pedreschi, et al., 2008).

Samples 5 and 6 have higher moisture content, derived from a smaller proportion of potato paste in the initial mixture, affecting the content of non-nitrogenated extract and energy (Table 2).

The moisture of each mixture was evaluated before and after extrusion (Table 3), using single screw and twin-screw equipment. In all the tests there was a reduction of moisture as a result of the extrusion, with this loss substantially greater when twin-screw equipment was used (Beltran \& Marcilla, 2012).

It should be noted that proximate analysis results made of the mixtures in these tests before subjecting them to extrusion cannot be compared with similar ones, because there are no products similar to the developed one. These analyses are useful to provide more information on the product and know the basic composition with which this food was started.

It was found that the samples had optimum moisture for extrusion in twin-screw equipment but not in single screw machines, because the latter require rather granular products with low moisture.

With respect to the new Law on the Nutritional Composition of Foods and their Publicity, No. 20.606, this solid, fresh product provides a caloric input lower than the maximum allowed for it not to be classified as "high in calories", since the samples vary within a range of 154 to $202 \mathrm{kcal} / 100 \mathrm{~g}$, while $275 \mathrm{kcal} / 100 \mathrm{~g}$ is the value for classifying the product as "high in calories." That is an initial advantage of the product under development, to allow it to fulfill the later objectives.

\subsection{Absorption of oil by potatoes}

Oil absorption in the frying operation is high (Figure la and $1 \mathrm{~b}$ ), similar to some traditional potato samples (commercial sample absorption). These results indicate that the mixtures used do not allow an improvement of the product in this respect (Pedreschi, et al., 2004).

Table 1. Composition of ingredients in the selected mixtures.

\begin{tabular}{|c|c|c|c|c|c|}
\hline Sample & Potato paste $\%$ & Rice flour \% & Dried potatoes $\%$ & Xanthan gum (g/kg) & Prototype \\
\hline 1 & 70 & 30 & 0 & - & A \\
\hline 2 & 70 & 30 & 0 & 1 & A \\
\hline 3 & 60 & 30 & 10 & - & $\mathrm{B}$ \\
\hline 4 & 60 & 30 & 10 & 1 & B \\
\hline 5 & 80 & 20 & 0 & & $\mathrm{C}$ \\
\hline 6 & 80 & 20 & 0 & 1 & $\mathrm{C}$ \\
\hline
\end{tabular}

Table 2. Proximate physicochemical analysis of the mixtures before extrusion.

\begin{tabular}{|c|c|c|c|c|c|c|c|}
\hline Sample & $\begin{array}{l}\text { Moisture } \\
(\mathrm{g} / 100 \mathrm{~g})\end{array}$ & $\begin{array}{c}\text { Proteins } \\
(\% \mathrm{Nx} 5.95)\end{array}$ & $\begin{array}{c}\text { Lipids } \\
(\mathrm{g} / 100 \mathrm{~g})^{*}\end{array}$ & $\begin{array}{c}\text { Ash } \\
(\mathrm{g} / 100 \mathrm{~g})\end{array}$ & $\begin{array}{l}\text { Raw fiber } \\
(\mathrm{g} / 100 \mathrm{~g})^{* *}\end{array}$ & $\begin{array}{c}\text { Non-nitrogenated } \\
\text { extract }(\mathrm{g} / 100 \mathrm{~g})\end{array}$ & $\begin{array}{c}\text { Energy } \\
(\mathrm{kcal} / 100 \mathrm{~g})\end{array}$ \\
\hline 1 & 53.9 & 2.7 & $\mathrm{ND}$ & 0.6 & $\mathrm{ND}$ & 42.8 & 182 \\
\hline 2 & 53.8 & 2.7 & ND & 0.6 & ND & 42.9 & 182 \\
\hline 3 & 48.6 & 3.2 & $\mathrm{ND}$ & 0.8 & ND & 47.4 & 202 \\
\hline 4 & 49.3 & 3.2 & ND & 0.8 & ND & 46.7 & 200 \\
\hline 5 & 59.7 & 2.2 & ND & 0.7 & ND & 37.4 & 158 \\
\hline 6 & 60.8 & 2.2 & ND & 0.7 & ND & 36.3 & 154 \\
\hline
\end{tabular}

${ }^{\star}$ Limit of detection $\leq 0.52 \mathrm{~g} / 100 \mathrm{~g} ;{ }^{* *}$ Limit of detection $\leq 0.59 \mathrm{~g} / 100 \mathrm{~g}$. ND: no detected.

Table 3. Results of moisture of the mixtures before and after extrusion.

\begin{tabular}{|c|c|c|c|c|c|c|}
\hline \multirow[b]{2}{*}{ Sample } & \multicolumn{3}{|c|}{ Single screw extrusion } & \multicolumn{3}{|c|}{ Twin-screw extrusion } \\
\hline & $\begin{array}{l}\% \text { moisture at } \\
\text { extruder inlet }\end{array}$ & $\begin{array}{c}\% \text { moisture at } \\
\text { extruder outlet }^{\mathrm{b}}\end{array}$ & $\begin{array}{c}\% \text { moisture } \\
\text { loss }^{c}\end{array}$ & $\begin{array}{l}\% \text { moisture at } \\
\text { extruder inlet }\end{array}$ & $\begin{array}{c}\% \text { moisture at } \\
\text { extruder outlet }^{\mathrm{b}}\end{array}$ & $\%$ moisture loss ${ }^{c}$ \\
\hline 1 & 50.9 & 44.75 & 6.15 & 51.44 & 36.9 & 14.54 \\
\hline 2 & 56.43 & 47.4 & 6.28 & 55.05 & 43.41 & 11.64 \\
\hline 3 & 44.81 & 42.03 & 2.78 & 45.79 & 40.3 & 5.49 \\
\hline 4 & 57.86 & 45.56 & 10.03 & 57.9 & 41.79 & 16.11 \\
\hline 5 & 56.71 & 50.43 & 6.07 & 56.09 & 47.16 & 8.93 \\
\hline 6 & 59.87 & 49.8 & 10.07 & 60.09 & 51.23 & 8.86 \\
\hline
\end{tabular}

a,b,c, There are no significant differences between samples. 

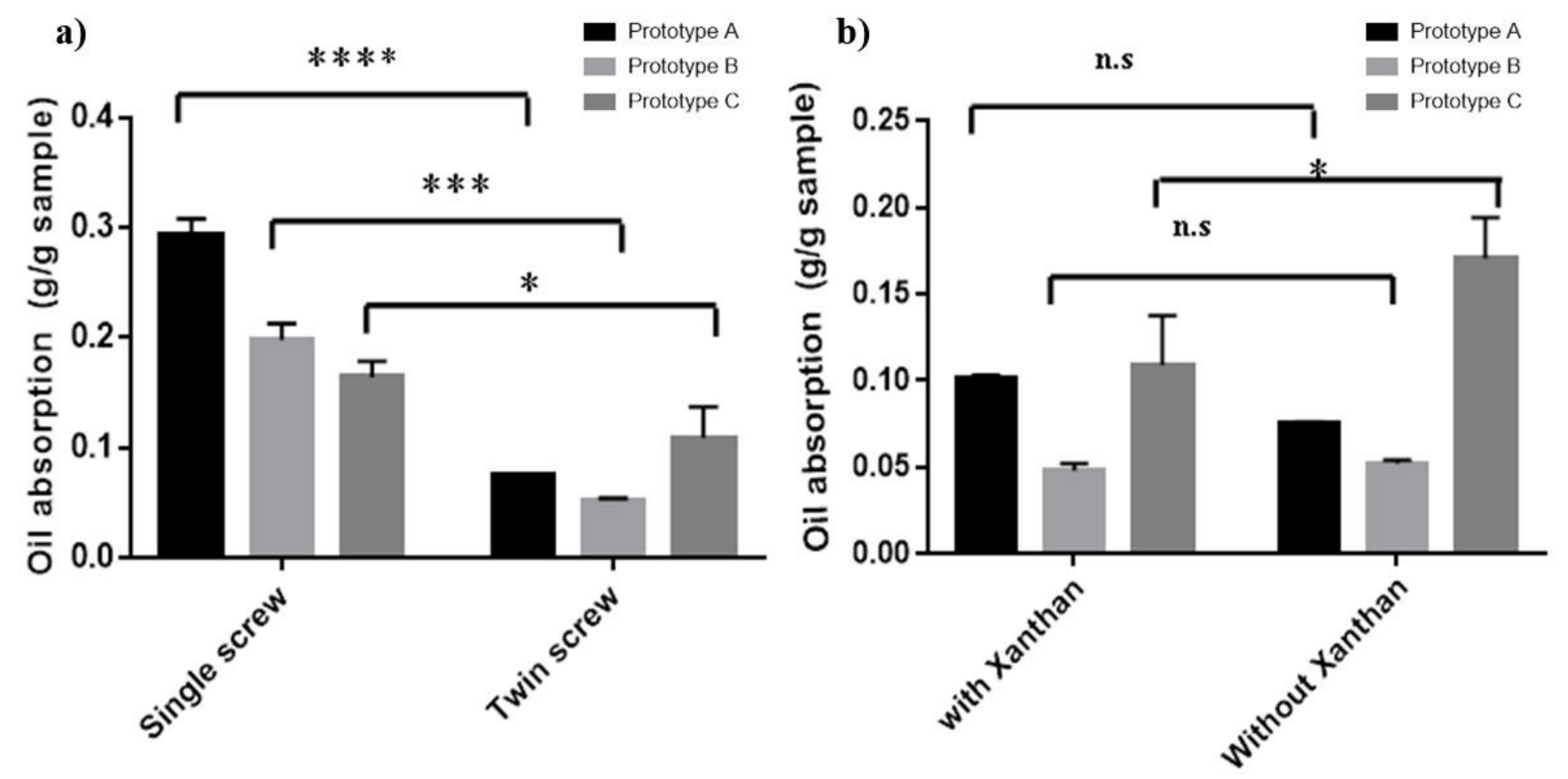

Figure 1. (a) Oil adsorption of prototype obtain in extrusion with single or twin screw $\left({ }^{\star \star \star \star} \mathrm{P}<0.0001 ;{ }^{\star * \star} \mathrm{P}=0.0002\right.$; $\left.{ }^{\star} \mathrm{P}=0,0354\right)$; (b) Effect of xanthan in the oil adsorption of each prototype using extrusion with twin screw (n.s. $=$ Non significant differences. $\left.{ }^{\star} \mathrm{P}=0,0106\right)$.

The results indicate that the samples obtained by twin-screws extrusion decrease oil absorption compared to extrusion with single screw after frying them, except sample 4 , in which it increased $15.18 \%$. Sample 1, or control, decreases $74.56 \%$, sample 2 decreases $51.41 \%$, sample 3 decreases $73.77 \%$, sample 4 decreases $75.9 \%$, and sample 5 decreases $32.62 \%$, making it the one that has the lowest oil absorption decrease. It is therefore seen that extrusion affects the determination of this parameter, yielding better results in the twin-screw extrusion.

The prototypes that have a higher percentage of rice flour are those that had the lowest oil absorption in the twin-screw extrusion. However, although the addition of Xanthan gum in single screw reduces oil absorption, this does not happen in twin-screw extrusion

With respect to the oil absorption compared to the control sample, the sample with $60 \%$ crude potato paste, $30 \%$ rice flower, and $10 \%$ dried potatoes, extruded in a twin-screw machine decreases it $82 \%$.

The results of lower oil absorption achieved in the tests compared to the commercial product at this stage are not sufficient for the major objectives of the project (useful tool to contribute to the reduction of obesity and overweight in Chile), so other alternatives must be studied to ensure the reduction of the final oil content of this analog of fried potatoes after frying.

It should be noted that the oil absorption results of the samples subjected to both extrusions turn out to be lower than the control sample, trade mark, and this presents the challenge of obtaining a prototype that generates a lower oil absorption by making the changes foreseen in the preliminary tests, where
Xanthan gum was added with the purpose of making the mass more manageable and able of trapping the water in the product to prevent it from jumping excessively in the frying. This additive did not give the expected results, and it was replaced in later tests.

\subsection{Microbiological analysis of the manufactured products}

The indicators of the presence of microorganisms were analyzed in the raw mixtures (before frying). The results show low contamination prior to the configuration, in the later handling of the already configured product; and in the refrigerated storage stage. The levels of presence of microorganisms observed can have an impact on the useful life of the raw mixtures, so the precautions in the hygienic handling of the process must be extreme after determining the useful life, either by refrigeration or by freezing.

Such contamination has no consequences on the consumers' health, because once the samples have been fried the presence of the microbes cannot be detected because the food has been heated to $160^{\circ} \mathrm{C}$, so all the microbial load has been destroyed.

With respect to the growth of the Enterobacteria, in both the fresh and the extruded mixtures the bacterial counts are within the range acceptable by the RSA $\left(5 \times 10^{-3}-5 \times 10^{-4} \mathrm{UFC} / \mathrm{g}\right)$, but it is seen that samples 1, 3, 4, and 6 only present Enterobacteria counts on days 1 and 3 before the extrusion. However, in samples 2 and 5 this does not happen, and they show counts higher than the initial ones. The presences of microorganism before the extrusion it is expected, because in the extrusion process high temperatures are applied, leading to a decreased microbial load. As to Staphylococcus aureus, no counts are recorded in the 
samples during the analysis days. This does not happen with samples 2 and 5, showing counts higher than the initial ones. This can be due to the input of dried potatoes that reactivate the initial load present in the product. As to S. aureus, no counts are obtained for samples during the analysis days.

In the case of RAM, if it is compared to a fresh product that does not require cooking, it has limits of $5 \times 10^{-4}-5 \times 10^{-5} \mathrm{UFC} / \mathrm{g}$, and the samples have results lower than those allowed.

The analyses of molds and yeasts show counts of $10^{1}$ to $10^{4} \mathrm{UFC} / \mathrm{g}$ for the fresh and for the extruded samples, except for sample 5 , which has a count of $1 \times 10^{7} \mathrm{UFC} / \mathrm{g}$, showing that the sample is undergoing important microbiological changes, so on day 10 the sample is already unstable, but the RSA does not set a range for these microorganisms in these products. The aerobic mesophiles had a tendency to decrease in five of the samples. However, there is an anomaly in sample 5, where the trend was to increase, confirming what was mentioned earlier with the addition of dried product.

Finally, with respect to storage, the sample can be stored under refrigeration $\left(4^{\circ} \mathrm{C}\right)$ during 9 days without presenting important microbiological changes. Therefore, it is possible to transport the samples in sealed containers in cold systems so the refrigeration temperature is maintained, to be used after two days of storage without risking any microbiological contamination.

The microbiological data obtained shown no presence of Salmonella in the raw samples, an important factor that allowed continuing with the unit process of using the pastes, complying with what is established by the RSA in Title V, Paragraph II, article 172, which establishes that there can be no Salmonella.

The analyses of molds and yeasts gave counts between $10^{1}$ to $10^{4} \mathrm{UFC} / \mathrm{g}$ for the fresh samples as well as for those extruded, except for sample 5 ( $80 \%$ potato/20\% rice without gum), where the count was $1 \times 10^{7} \mathrm{UFC} / \mathrm{g}$, indicating that the sample presented microbiologically important changes, so on day 10 the sample was already unstable. However, the RSA does not establish a range of these colonies for these products.

Finally, with respect to the storage, the sample can be stored under refrigeration $\left(4^{\circ} \mathrm{C}\right)$ during 9 days without presenting microbiologically important changes. Considering these results, it was concluded that it was possible to transport the samples in sealed containers in cold systems keeping the refrigeration temperature, to be used after two days of storage without running any risk of microbiological contamination.

During the frying, in preliminary tests, we got optimum conditions for the product, which were $160^{\circ} \mathrm{C}$ for 90 seconds of immersion in oil. These conditions favor a lower oil absorption as well as the product's nutritional quality, since scientific studies made confirm that the longer the exposure time, the higher the absorption of oil, generating acrylamide, which nowadays is considered as possibly cancer causing, by the International Agency for Research on Cancer (IARC). That is why it has the advantage of achieving the cooking and soft color characteristic of products fried in less contact time and temperature with oil compared to commercial fried potatoes distributed in the market.

\section{Conclusions}

In the case of fresh-chilled or frozen chips, the raw material must have a high content of total solids and a low content of reducing sugars and must preferably have an elongated or cylindrical shape to optimize yields. These characteristics are satisfactorily fulfilled by the potatoes of the Desiree variety.

It was observed that the samples had an optimum humidity to be subjected to extrusion in double screw equipment, not for a single screw, since this requires rather granulated, low humidity products.

It is important to note that the results of oil absorption, for the samples submitted in both extrusions, were lower than in the control sample, commercial product. This fact presents the challenge of obtaining a prototype that generates a lower absorption of oil, realizing the changes that are already glimpsed with the preliminary tests carried out.

There was no presence of microorganisms in the raw samples, main factor that allowed continuing with the unit operations of the process of using the pasta, complying with the provisions of the RSA, in Title V, Paragraph II, article 172.

During the frying process, in preliminary tests, it was possible to obtain the optimum conditions for the product: $160^{\circ} \mathrm{C}$, for 1 minute and 30 seconds of immersion in oil. These conditions are favorable, both in terms of the lower absorption of oil, and in relation to the level of nutritional quality of the product. The above is corroborated as scientific studies confirm that, the longer the exposure, the greater the absorption of oil, generating the acrylamide compound, considered today as possibly carcinogenic, by the IARC.

\section{Acknowledgements}

Support under Project FIA-USACH PYT-2015-0206 is gratefully acknowledged.

\section{References}

Arias, R., Pérez, G., \& Durán, C. (2007). Condiciones de operación de extrusores de tornillo simple para mixtures de harina y trigo. Parte 2: montaje, arranque y operación de una planta industrial. México: Programa de Ingeniería Química Ambiental, Facultad de Química, UNAM.

American Association of Cereal Chemists - AACC (2010). AACC Approved Methods of Analysis (11th Ed., Method 46-12, Approved 12.10.01). St. Paul, U.S.A: Cereals \& Grains Association. http:// dx.doi.org/10.1094/AACCIntMethod-46-12

Association of Official Analytical Chemists - AOAC. (1984). Official methods of analysis of the Association of Official Analytical Chemists (14th ed.). Arlington: AOAC.

Association of Official Analytical Chemists - AOAC. (1990). Official methods of analysis of the Association of Official Analytical Chemists (15th ed.). Arlington: AOAC.

Association of Official Analytical Chemists - AOAC. (1997) Official methods of analysis of the Association of Official Analytical Chemists (16th ed.). Arlington: AOAC. 
Association of Official Analytical Chemists - AOAC. (2000) Official methods of analysis of the Association of Official Analytical Chemists (Methods 925.10, 65.17, 974.24, 992.16, 17th ed). Gaithersburg: AOAC.

Association of Official Analytical Chemists - AOAC. (2003) Official Methods of Analysis (17th ed., Vol. I). DC, USA: Association of Analytical Washington.

Association of Official Analytical Chemists - AOAC. (2010). AOAC Official Method 962.09. Arlington: AOAC.

Association of Official Analytical Chemists - AOAC. (2012). AOAC official methods of analysis (18th ed.). Gaithersburg: AOAC.

Beltran, M., \& Marcilla, A. (2012). Tecnología de polímeros: procesado y propiedades. Valencia: Universidad de Alicante.

Bouchon, P. (2002). Modeling oil uptake during frying (PhD thesis). School of Food Biosciences, University of Reading, Reading.

Bouchon, O. P., Aguilera, J., \& Pyled, D. (2003). Structure Oil-Absorption Relationships During Deep-Fat Frying. Journal of Food Science, 68(9), 2711-2716. http://dx.doi.org/10.1111/j.1365-2621.2003.tb05793.x.

Bühler. (2017a, Julio 16). Buhler process technologies: obtenido de extrusion \& dough preparation. Retrieved from http://www.buhlergroup.com/ global/en/process-technologies/extrusion-dough-preparation.htm

Bühler. (2017b, Julio 16). Buhler tecnologías de procesos: obtenido de extrusión. Retrieved from http://www.buhlergroup.com/southamerica/ es/tecnologias-de-procesos/extrusion.htm

Chile, Ministerio de Salud. (2013, May 13). Reglamento Sanitario de los Alimentos (RSA). Diario Oficial.

Chile, Ministerio de Agricultura, Instituto de Investigaciones Agropecuarias - INIA. (2017). Manual del cultivo de la papa en Chile (Boletín INIA, No. 10). Santiago: INIA.

Durán, S., Valdés B, P., Godoy C, A., \& Herrera, T. (2014). Hábitos alimentarios y condición física en estudiantes de pedagogía en educación física. Revista Chilena de Nutrición, 41(3), 251-259. http:// dx.doi.org/10.4067/S0717-75182014000300004.

Food and Agriculture Organization of the United Nations - FAO, World Health Organization - WHO. (1997a) Grasas y aceites en la nutrición humana: las grasas y aceites en la nutrición humana. Rome: FAO/WHO.

Food and Agriculture Organization of the United Nations - FAO, World Health Organization - WHO. (1997b). Grasas y aceites en la nutrición humana. Capítulo 6: selección de usos de las grasas y de los aceites en la alimentación. Rome: FAO/WHO.
Hagenimana, A., Ding, X., \& Fang, T. (2006). Evaluation of rice flour modified by extrusion cooking. Journal of Cereal Science, 43(1), 38-46. http://dx.doi.org/10.1016/j.jcs.2005.09.003.

Hernández, M., \& Sastre, A. (1999). Tratado de nutrición. Madrid: Díaz de Santos.

Herrera, C., Lirab, M., \& Kainc, J. (2017). Socioeconomic vulnerability and obesity in Chilean schoolchildren attending first grade: comparison between 2009 and 2013. Revista Chilena de Pediatria, 88(6), 736-743. http://dx.doi.org/10.4067/S0370-41062017000600736.

Huang, Y. L., \& Ma, Y. S. (2015). The effect of extrusion processing on the physiochemical properties of extruded orange pomace. Food Chemistry, 192, 363-369. http://dx.doi.org/10.1016/j.foodchem.2015.07.039.

Pedreschi, F., Cocio, C., Moyano, P., \& Troncoso, E. (2008). Oil distribution in potato slice during frying. Journal of Food Engineering, 87(2), 200-2012. http://dx.doi.org/10.1016/j.jfoodeng.2007.11.031.

Pedreschi, F., Moyano, P., Kaack, K., \& Granby, K. (2005). Color changes and acrylamide formation in fried potato slices. Food Research International, 38(1), 1-9. http://dx.doi.org/10.1016/j. foodres.2004.07.002.

Pedreschi, F., Kaack, K., \& Granby, K. (2004). Reduction of acrylamide formation in potato slices during frying. Lebensmittel-Wissenschaft + Technologie, 37(6), 679-685.

Schmidt-Hebbel, H. (1981). Avances en Ciencia y Tecnología de Alimentos. Santiago: Alfabeta Impresores.

Servicio Agrícola y Ganadero - SAG, División Semillas. (2012). Variedades certificadas de papas. Chile: Departamento de Clientes y Comunicaciones.

Veronese, N., Stubbs, B., Noale, M., Solmi, M., Vaona, A., Demurtas, J., Nicetto, D., Crepaldi, G., Schofield, P., Koyanagi, A., Maggi, S., \& Fontana, L. (2017). Fried potato consumption is associated with elevated mortality: an 8-y longitudinal cohort study. The American Journal of Clinical Nutrition, 106(1), 162-167. http://dx.doi.org/10.3945/ ajcn.117.154872. PMid:28592612.

Vio, F. (2012). La obesidad y nuestro desarrollo como país. Santiago, Chile: Instituto de Nutrición y Tecnología de Alimentos. Retrieved from inta.cl/es/opinion/la-obesidad-y-nuestro-desarrollo-como-pais

Zhang, B., Dhital, S., Flanagan, B. M., Luckman, P., Halley, P. J., \& Gidley, M. J. (2015). Extrusion induced low-order starch matrices: enzymic hydrolysis and structure. Carbohydrate Polymers, 134, 485-496. http://dx.doi.org/10.1016/j.carbpol.2015.07.095. PMid:26428150. 